\title{
Influence of User Generated Content (UGC) on Tourist Satisfaction in Pre-Purchase Period of Tourism in Pakistan
}

Asfandyar Khan, Aslan Amat Senin, Urooj Zulfiqar, Javeria Ashfaq

To Link this Article: http://dx.doi.org/10.6007/IJARBSS/v12-i1/12237

DOI:10.6007/IJARBSS/v12-i1/12237

Received: 13 November 2021, Revised: 16 December 2021, Accepted: 30 December 2021

Published Online: 26 January 2022

In-Text Citation: (Khan et al., 2022)

To Cite this Article: Khan, A., Senin, A. A., Zulfiqar, U., \& Ashfaq, J. (2022). Influence of User Generated Content (UGC) on Tourist Satisfaction in Pre-Purchase Period of Tourism in Pakistan. International Journal of Academic Research in Business and Social Sciences, 12(1), 2512-2522.

Copyright: @ 2022 The Author(s)

Published by Human Resource Management Academic Research Society (www.hrmars.com)

This article is published under the Creative Commons Attribution (CC BY 4.0) license. Anyone may reproduce, distribute, translate and create derivative works of this article (for both commercial and non0-commercial purposes), subject to full attribution to the original publication and authors. The full terms of this license may be seen at: http://creativecommons.org/licences/by/4.0/legalcode

Vol. 12, No. 1, 2022, Pg. 2512- 2522

Full Terms \& Conditions of access and use can be found at http://hrmars.com/index.php/pages/detail/publication-ethics 


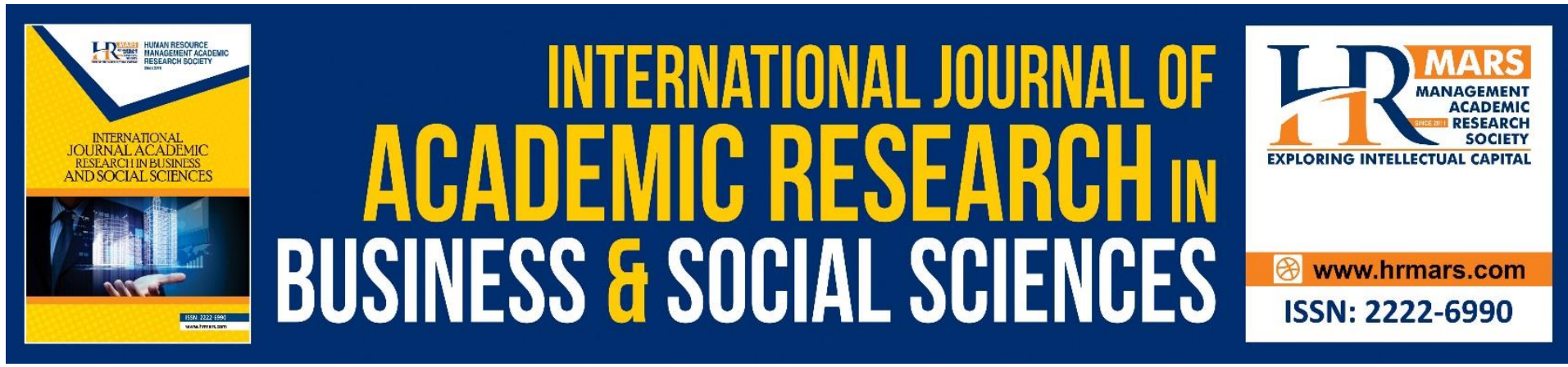

\title{
Influence of User Generated Content (UGC) on Tourist Satisfaction in Pre-Purchase Period of Tourism in Pakistan
}

\author{
Asfandyar Khan ${ }^{1}$, Aslan Amat Senin ${ }^{1}$, Urooj Zulfiqar ${ }^{1}$, Javeria \\ Ashfaq $^{2}$ \\ ${ }^{1}$ Azman Hashim International Business School, Universiti Teknologi Malaysia, Sultan Ibrahim \\ Chancellery Building, Jalan Iman, 81310 Skudai, Johor, Malaysia, ${ }^{2}$ Department of Mass \\ Communication, National University of Modern Languages (NUML Rawalpindi), Khadim \\ Hussain Rd, Lalazar, Rawalpindi, Punjab 46000 \\ Corresponding Author Email: kasfandyar@graduate.utm.my
}

\begin{abstract}
Social networking sites have a significant influence on the user's behaviors. Previous researches related to social media and tourism focused on social media's role that it plays in the whole process of travel. Social media usually plays an influential part in the whole process of deciding the pre-trip phase. The information associated with the tourism destinations has a substantial impact on satisfaction of the customers having access to social media. This topic is emerging, so the literature is limited in investigating the existing relationship that is between tourism and social media. This study aims to figure out how user-generated content (UGC) influence the tourist's satisfaction in the pre-trip period in Pakistan. The quantitative survey method used and through online surveys data collected from social media (Facebook) users who were the members of the Facebook tourism groups in Pakistan. The results showed that UGC has a strong influence on tourist's satisfaction in the pre-purchase period. People get satisfied with the user-generated content in pre-trip phase. The satisfaction of the consumers in the pre-purchase period of tourism plays a significant role in the tourism market. This research will help the tourism market and Users who generate content for social media in better understanding the user's behaviors in the pre-purchase period of tourism.
\end{abstract}

Keywords: Social Media, Influence on Customers, Tourism, Pre-Purchase Period, UserGenerated Content, Satisfaction, Pakistan.

\section{Introduction}

Social media's use is gradually increasing throughout the world (Kim et al., 2017). Online media is well known in exchanging the information and knowledge (Agnihotri et al., 2016). According to Lachlan, Spence, Edwards, Reno, and Edwards (2014), social media applications for example Facebook, Twitter, Instagram are used by several people to get information and share it on daily basis (Kwak, Lee, Park, \& Moon, 2010). Customers also use social media to connect with people and also organisations. 
Furthermore, people share their information, experiences, advice, reviews, tips and warnings with their friends they connected with (Sema, 2013). Other than exchange of information people uses social media to clear their doubts and also share their interests with others (Luo et al., 2011). This exchange of information and knowledge about others experiences help in pre-purchase period of tourism. Zeng and Gerritsen (2014) also figure out that it influences the decision making of customers (Sema, 2013).

The phenomena of online communities of travel are rapidly increasing, which encourages the travelling behaviour of consumers (Casalo et al., 2011). In general, social media apps and content produced on it is considered as an important tool for users in pre-purchase period of travelling (Leung, Law, van Hoof, \& Buhalis, 2013). It plays a prominent role in changing the decisions of the users regarding tourism services (Giglio, Bertacchini, Bilotta, \& Pantano, 2019). For that the content produced by others can help in making a sincere decision (Utz, 2010). Usually this content is created by consumer's family, friends and organisations related to tourism or sometimes this information come from the strangers (Casaló et al., 2011). User-generated content (UGC) has various forms of information like images, videos and also texts (Di Minin et al., 2015). They post the data or knowledge they have regarding the place customers are interested in visiting. The image of place which shared on social media has a substantial impact on costumers because this image will give complete information about how this place looks like (Giglio et al., 2019). UGC not only provide information regarding the destination but also helps in planning and organising the whole trip (Nezakati et al., 2015; Zeng \& Gerritsen, 2014). Focusing on the role of social media, it strongly influences the users in the pre-visit period of tourism, and it also generates loyalty with the destination (Fowler, 2019).

In the pre-purchase period of tourism, the prior element is the trustworthiness of information taken provided by social media sites (Leung et al., 2013). It is considered to be the most trustworthy source from where they can get relevant information regarding tourism (Yoo \& Gretzel, 2011). The recommendations that come from close people or reallife friends can increase the trust level (Turcotte et al., 2015). Travellers trust the information available online for planning trips in pre-purchase period of tourism (Yoo \& Gretzel, 2011). Trip planning has a significant influence on social media (Xiang \& Gretzel, 2010). Access to right amount of information provided on social media motivates trigger travellers for trip planning (Kim et al., 2017). There is a bridge created between the real and imaginary world for tourism customers, which allows them to plan the trip (Giglio et al., 2019). Social media can influence the expectations regarding the visiting place and also influence the satisfaction level. Before visiting the place, User-generated content increases the satisfaction level of travellers (Fowler, 2019)

Based on the current reviewed literature, this study focused on the following objectives:

- To examine the relationship between information sharing intention and tourist satisfaction.

- To identify the relationship between information seeking motive and tourist satisfaction.

- To investigate the relationship between user-generated content and tourist satisfaction.

\section{Literature Review}

With technology development, the trend of social media is increasing worldwide. Utilising technology became a routine for social media users. Thus, highlight number of applications 
that are internet-based which creates an ideology and technological foundations of Web 2.0, also creates an information exchange platform for individuals where user-generated content is available (Kaplan \& Haenlein, 2010). The individuals exchange and share the conventional ideas, videos, texts, images and other kind of information with other people (Altinay et al., 2016). It plays a vital role in creating a platform through which people can connect with their family and friends, and also share their personal experiences and statuses (Fowler, 2019).

Researchers investigated the prominent role of social networking sites in exchanging and sharing tourism related information. This information also helps in deciding on the trip (Zeng \& Gerritsen, 2014). Like Munar and Jacobsen (2014) found that social media is the appropriate platform for sharing of experiences related to tourism. Several types of research find out that users use social media to get the relevant guidelines for their future tour trips (Sema, 2013). So these platform plays a vital role in phase of decision making regarding tourism (Fotis et al., 2012). So social media and tourism connected in this way that there is a strong impact of UGC on the pre-trip phase of tourism (Fowler, 2019).

Online media has an influence on consumers purchase intentions while making decision for tourism. Hence, it is not necessary that purchasing influence the complete behaviour of the consumer, but it has a mediating effect on the whole process of decision making (Li et al., 2010). Individuals search for information related to the places where they want to visit. It becomes easy for users to collect the latest and most relevant information related to their interest (Luo et al., 2011). There is also another essential factor that is the credibility of the source. The reviews of the products and experiences play a role in decision making (Yogesh \& Yesha, 2014). It believed by the people that the recommendations of their friend, family and close people would have more authenticity. Therefore, these recommendations help tourists to make a proper decision regarding tourism (Kim et al., 2017). However, it is also found out by the researchers that the trust level on the reviews on social media is almost the same for the close people and strangers (Yogesh \& Yesha, 2014). Tourism information provided on social media sites also enhances the tourism market, as with the dissemination of this tourism-related knowledge, it benefits the market of tourism (Kim et al., 2017). There is number of options to explore and focus on, as tourism and social media are still emerging (Zeng \& Gerritsen, 2014).

In the current literature, the rapid growth of user-generated content on various social media platforms (Sigala \& Marinidis, 2009). As the User-generated content (UGC) is growing, it directly affects the whole process of travelling positively both in pre-travelling phase but also post-travelling phase (Nezakati et al., 2015). Information related to tourism on social media is considered to be an informative and helpful material for tourists. It helps them in the planning process for the trip by providing the guidelines (Xiang \& Gretzel, 2010). UGC on social media provides information by tourism-tie sources, strong-tie sources and weak-tie sources. These sources also related to the satisfaction level of the consumers. This UGC also creates expectations for the tour places (Kaosiri et al., 2019). Understanding the UGC is essential because it up rises the market of tourism (Mkono \& Tribe, 2017).

\section{Methodology}

The quantitative survey method used for data (Zeng \& Gerritsen, 2014). An online survey conducted to find out the UGC's influence on the satisfaction of tourists in the pre-purchase period (Ayeh, Au, \& Law, 2013; Kang \& Schuett, 2013; Senders, Govers, \& Neuts, 2013). The data collected from the members added in tourism groups on Facebook, aged 18-35 in Pakistan (Yoo \& Gretzel, 2011). 


\section{Data Collection}

The data collected in two weeks and four hundred sixty-seven responses collected out of which 450 responses analysed as 17 were half-filled and not appropriate for analysis. The target population was the youth of Pakistan aged 18-35 interested in tourism (Yoo \& Gretzel, 2011). The data was collected from all over Pakistan, as in the questionnaire the researcher asked the respondents to mention their hometown; this helped the researcher to know from where the respondents belonged. Five categories made by the researcher Punjab, Sindh, Baluchistan, KPK and Islamabad. The data analysed by using descriptive statistics. For further analysis of data regression test run by using SPSS software.

\section{Measures}

The questionnaire designed based on literature. Introductory paragraph contained the information related to the researcher and the purpose of the research. The time required to fill out the questionnaire also mentioned there. This information increases the credibility of the research (Martilla \& James, 1977). Five-point Likert-type scale from Strongly disagree (1) to Strongly agree (5) was adapted from (Ayeh et al., 2013) for five items. Three items adopted from Bhattacherjee (2001) for social media using intentions. Rest of four items for information sharing intentions was adapted by Kim et al. (2017) by using five-point scale starting from strongly disagree (1) to strongly agree (5). Five items were adapted to measure the tourist's satisfaction by using (Kaosiri et al., 2019) five-point Likert scale from strongly disagree (1) to strongly agree (5). For the influence of online User-Generated content fivepoint scale rated from strongly disagree (1) to strongly agree (5) was adapted for three items (Casaló et al., 2011).

\section{Findings}

Table 1.1 shows the description of the sample collected in this research. Most of the participants who filled the questionnaire were youth. The value of lower mean (mean = 0.504 ) of the variable "age" and its Standard Deviation (SD $=0.501$ ) shows that a more significant number of the participants were young people. Forty-one per cent of the respondents were females. This percentage is itself good while keeping in mind that the usage of social media is so much higher in males as compared to females. Most respondents belonged from Punjab (Mean $=0.37$ ) this is because Punjab has the highest population. This number skewed because of federal area, where the research originated is over-represented (mean $=0.1067)$. The second most represented province in Sindh (mean $=0.2044)$. The third most represented province in Khyber Pakhtunkhwa $(K P K)$ (mean $=0.1933)$. The province with the lowest amount of representation in the sample is Baluchistan (mean $=0.127$ ). These results are in-line with the demographic distribution of Pakistan, excluding Federal area. More precisely it is a representative of digital Pakistan. 
Table 1.1: Descriptive Statistics ( $N=450)$

\begin{tabular}{|c|c|c|c|c|c|}
\hline & $\mathrm{N}$ & Minimum & Maximum & Mean & Std. Deviation \\
\hline Age & 450 & .00 & 1.00 & .5035 & .50057 \\
\hline Gender $($ Female $=1)$ & 450 & .00 & 1.00 & .4149 & .49328 \\
\hline Punjab & 450 & .00 & 1.00 & .3689 & .48304 \\
\hline KPK & 450 & .00 & 1.00 & .1933 & .39535 \\
\hline Sindh & 450 & .00 & 1.00 & .2044 & .40374 \\
\hline Baluchistan & 450 & .00 & 1.00 & .1267 & .33297 \\
\hline Federal & 450 & .00 & 1.00 & .1067 & .30903 \\
\hline Valid N (listwise) & 450 & & & & \\
\hline
\end{tabular}

\section{Correlation}

Table1.2 shows Pearson's correlations among the variables. There is dependent, and some independent variables shown in the table. The results show that independent variables have positive and significant relationship with the other dependent variable, i.e., Tourist Satisfaction. Three variables have a significant relationship i.e., Information Sharing Intention $(r(450)=0.616, p=0.01$, two-tailed) and Information Seeking Motive $(r(450)=$ 0.702, $p=0.01$, two-tailed) and User Generated Content $(r(450)=0.683, p=0.01$, twotailed) are positively and significantly related with the dependent variable i.e., Tourist Satisfaction. Correlation.

Table 1.2: Correlation

\begin{tabular}{lllllll}
\hline & 1 & 2 & 3 & 4 & 5 & 6 \\
\hline Gender (Female = 1) & 1 & & & & & \\
Age (Below 26 = 1) & $127^{* *}$ & 1 & & & & \\
Information Sharing Intention & .022 & .077 & 1 & & & \\
Information Seeking Motive & .030 & .019 & $578^{* *}$ & 1 & & \\
Tourist Satisfaction & .041 & .064 & $616^{* *}$ & $702^{* *}$ & 1 & \\
User-Generated Content & .018 & .031 & $535^{* *}$ & $695^{* *}$ & $683^{* *}$ & 1 \\
\hline
\end{tabular}

**. Significance of correlation at the 0.01 level (2-tailed).

\section{Multiple Regression}

The study uses multiple regression to find out the effects of multiple variables on tourist Satisfaction in Pakistan.

Table 1.3 describes the effect of different variable on Tourist Satisfaction with $\left(\Delta R^{2}=0.604\right.$, $\left.F_{(3,425)}=219.038, p<0.001\right)$. This model explains a $60.7 \%$ variation in the dependent variable. Here all the variables show significant results, Information Sharing Intention $(\beta=0.253, p$ $<0.05)$, Information Seeking Motive $(\beta=0.285, p<0.05)$ and User Generated Content $(\beta=$ $0.286, p<0.05)$ is significantly and positively related to the dependent variable. In the table ISI stands for "Information sharing intentions", ISM stands for "Information seeking motive", and UGC stands for "User-generated content". 
Table1.3: Tourist Satisfaction

Multiple Regression with dependent variable Tourist Satisfaction

\begin{tabular}{llllll}
\hline & $\boldsymbol{\beta}$ & SE & P Value & $\mathbf{t}$ & Decision \\
\hline (Constant) & .732 & .111 & & 6.572 & \\
ISI & .253 & .038 & .000 & 6.636 & Supported \\
ISM & .285 & .038 & .000 & 7.567 & Supported \\
UGC & .286 & .04 & .000 & 7.159 & Supported \\
Adjusted R & \multicolumn{2}{c}{$0.604(3,425)$} & & & \\
$\Delta \mathrm{R}^{2}$ & 0.607 & & & \\
$\mathrm{~F}$ & $219.038 * * *$ & & & \\
${ }^{*} p<0.1,{ }^{* *} p<0.05, * * * p<0.001$ & & & &
\end{tabular}

\section{Discussion and Conclusion}

As technology is growing, social media has become the everyday routine's entertainment in daily life (Siddiqui \& Singh, 2016). Today's world powerful tool is social media as a greater number of people are using it and share their experiences and thoughts on it. As before experiencing tourism, consumers take advice from social media. The higher percentage of customer's relay on UGC when they are planning to visit a destination (Simms \& Gretzel, 2013). People find useful information regarding their destinations through social media. Travellers reviews considered as an influential source for planning in pre-trip phase. Xiang and Gretzel (2010) confirmed that there is a high significance of social media in the process of searching for information associated tourism. According to Zeng and Gerritsen (2014) that the concept of social media is still new and in growth stage. Thus, tourism and social media have to be explored more with different aspects.

Drastic changes were seen in tourism market with the rise in the usage of social media. As social media has become a tool for enhancing tourism as it shares experiences and reviews which attract the costumers in pre-purchase period to plan a trip (Hua et al., 2017). With the increase in UGC related to tourism, competition in destinations has also increased. Tourism marketers are searching for ways to attract customers to the destinations. This attraction of tourists is famous for the tourism market to realise the traveller's behaviours and consider costumer's satisfaction regarding destinations (Bigne et al., 2001). So tourism marketers should use new technologies to increase tourism and also understand the consumer's satisfaction level (Litvin, Goldsmith, \& Pan, 2008). So basically by understanding Usergenerated content, there are more chances in rising in the tourism industry (Mkono \& Tribe, 2017).

This study concludes that user-generated content and satisfaction of tourists have a healthy relationship. UGC has a positive impact on tourist's satisfaction in the pre-trip period. individuals use social media for planning trips and get influenced by the user-generated content on it. This study contributes to the tourism market as it tells about the influences of travellers and their intentions to use social media.

\section{Theoretical and Contextual Contribution}

The main contribution of this research study is to propose a model of tourist satisfaction and its precedents such as information sharing intention, information seeking motive and usergenerated content. Little research related to tourist satisfaction in the context social media is available in the current literature. The current study shall contribute to the body of knowledge by investigating the role of information sharing intention, information seeking 
motive and user-generated content in the context of social media. Therefore, the present research contributes significantly to the tourism literature by examining how there is a strong, direct, and positive relationship between of information sharing intention, information seeking motive and user-generated content and tourist satisfaction. Thus, empirical research will describe the term tourist satisfaction more prominently in the context of social media.

This research has a wide range of practical ramifications for tourism authorities and marketing firm. Because social media is the most widely used source of information and entertainment in today's society, it plays an important part in tourist satisfaction. Social media has become a powerful tool for promoting travel destinations. Furthermore, this research makes a practical contribution in the fields of tourist marketing and tourism information in social media, which will ultimately result in the improvement of the tourism sector in social media. Although this study makes a theoretical contribution, it also makes a practical contribution by giving empirical evidence that information sharing intention, information seeking motive and user-generated content and tourist satisfaction via social media. This information will assist the DMOs in establishing the content that tourists looking for, which will raise the value of the tourist destination and attract an increasing number of tourists. Therefore, it is recommended to the DMOs to improve information content quality in social media. This is because social media are valued by tourists due to the wealth of tourism information they provide (Költringer \& Dickinger, 2015). The majority of empirical investigations have concentrated primarily on the study setting in Western contexts. but litter is known for Asian Context especially in Pakistani Context. Thus, this study shall contribute to the body of knowledge in understanding that information sharing intention, information seeking motive and user-generated content and tourist satisfaction in the context of Pakistan.

\section{Limitation of the Study}

There are various limitations in the current study. The limitations of the current study for data collection are through online surveys. Hence, the online survey does not provide information about respondent's nature, their qualification, their interests. Another limitation of current study is that data collected from Facebook tourism groups. There is number of people who randomly add in these groups and not like to experience tourism. The researcher was unable to identify these people in this regard. The researcher was also not able to identify their past experiences regarding tourism. Other limitations of this study are that this study is in the context of Pakistan. Which cannot generalise it to Western and European countries costumers as they have different mindsets as compared to the Asian countries.

There are several implications of this study. As this research focused on Facebook tourism groups, other social media applications should consider for future researches. As different tourists use different social media sites for suggestions (Hausmann et al., 2018). Influence of UGC on Instagram users related to tourism researcher. As Instagram is rapidly becoming the most used social media application, people are more influencing through Instagram's posts and statuses. Secondly, content analysis of User-generated content can also be done to understand the nature of the content produced for tourism, and it will also help the tourism market. In-depth interviews can be done to figure out the tourist's intentions to have access to UGC. For upcoming studies, this study can be replicated in other countries as well to figure out the influence of UGC created by social media users. 


\section{References}

Agnihotri, R., Dingus, R., Hu, M. Y., \& Krush, M. T. (2016). Social media: Influencing customer satisfaction in B2B sales. Industrial Marketing Management, 53, 172-180.

Altinay, Z., Saner, T., Bahçelerli, N. M., \& Altinay, F. (2016). The role of social media tools: accessible tourism for disabled citizens. Journal of Educational Technology \& Society, 19(1), 89-99.

Ayeh, J. K., Au, N., \& Law, R. (2013). “Do we believe in TripAdvisor?” Examining credibility perceptions and online travelers' attitude toward using user-generated content. Journal of Travel Research, 52(4), 437-452.

Bhattacherjee, A. (2001). An empirical analysis of the antecedents of electronic commerce service continuance. Decision Support Systems, 32(2), 201-214.

Bigne, J. E., Sanchez, M. I., \& Sanchez, J. (2001). Tourism image, evaluation variables and after purchase behaviour: inter-relationship. Tourism management, 22(6), 607-616.

Casaló, L. V., Flavián, C., \& Guinalíu, M. (2011). Understanding the intention to follow the advice obtained in an online travel community. Computers in Human Behavior, 27(2), 622-633.

Di Minin, E., Tenkanen, H., \& Toivonen, T. (2015). Prospects and challenges for social media data in conservation science. Frontiers in Environmental Science, 3, 63.

Fotis, J. N., Buhalis, D., \& Rossides, N. (2012). Social media use and impact during the holiday travel planning process: Springer-Verlag.

Fowler, K. A. (2019). \# tourism: the influence of social media on satisfaction with visitor experiences in Churchill, Manitoba.

Giglio, S., Bertacchini, F., Bilotta, E., \& Pantano, P. (2019). Using social media to identify tourism attractiveness in six Italian cities. Tourism management, 72, 306-312.

Hausmann, A., Toivonen, T., Slotow, R., Tenkanen, H., Moilanen, A., Heikinheimo, V., \& Di Minin, E. (2018). Social media data can be used to understand tourists' preferences for nature-based experiences in protected areas. Conservation Letters, 11(1), e12343.

Hua, L. Y., Ramayah, T., Ping, T. A., \& Jun-Hwa, C. (2017). Social Media as a Tool to Help Select Tourism Destinations: The Case of Malaysia. Information Systems Management, 34(3), 265-279.

Kang, M., \& Schuett, M. A. (2013). Determinants of sharing travel experiences in social media. Journal of Travel \& Tourism Marketing, 30(1-2), 93-107.

Kaplan, A. M., \& Haenlein, M. (2010). Users of the world, unite! The challenges and opportunities of Social Media. Business horizons, 53(1), 59-68.

Kim, S.-E., Lee, K. Y., Shin, S. I., \& Yang, S.-B. (2017). Effects of tourism information quality in social media on destination image formation: The case of Sina Weibo. Information \& Management, 54(6), 687-702. doi:https://doi.org/10.1016/j.im.2017.02.009

Költringer, C., \& Dickinger, A. (2015). Analyzing destination branding and image from online sources: A web content mining approach. Journal of business research, 68(9), 18361843. doi:https://doi.org/10.1016/j.jbusres.2015.01.011

Kwak, H., Lee, C., Park, H., \& Moon, S. (2010). What is Twitter, a social network or a news media? Paper presented at the Proceedings of the 19th international conference on World wide web.

Lachlan, K. A., Spence, P. R., Edwards, A., Reno, K. M., \& Edwards, C. (2014). If you are quick enough, I will think about it: Information speed and trust in public health organizations. Computers in Human Behavior, 33, 377-380. 
Leung, D., Law, R., van Hoof, H., \& Buhalis, D. (2013). Social Media in Tourism and Hospitality: A Literature Review. Journal of travel \& tourism marketing, 30(1-2), 3-22. doi:https://doi.org/10.1080/10548408.2013.750919

Li, M., Cai, L. A., Lehto, X. Y., \& Huang, J. (2010). A missing link in understanding revisit intention-The role of motivation and image. Journal of travel \& tourism marketing, 27(4), 335-348.

Litvin, S. W., Goldsmith, R. E., \& Pan, B. (2008). Electronic word-of-mouth in hospitality and tourism management. Tourism management, 29(3), 458-468.

Luo, M. M., Chea, S., \& Chen, J.-S. (2011). Web-based information service adoption: A comparison of the motivational model and the uses and gratifications theory. Decision Support Systems, 51(1), 21-30.

Martilla, J. A., \& James, J. C. (1977). Importance-performance analysis. Journal of marketing, 41(1), 77-79.

Mkono, M., \& Tribe, J. (2017). Beyond reviewing: Uncovering the multiple roles of tourism social media users. Journal of travel research, 56(3), 287-298.

Munar, A. M., \& Jacobsen, J. K. S. (2014). Motivations for sharing tourism experiences through social media. Tourism Management, 43, 46-54.

Narangajavana Kaosiri, Y., Callarisa Fiol, L. J., Moliner Tena, M. A., Rodríguez Artola, R. M., \& Sanchez Garcia, J. (2019). User-generated content sources in social media: A new approach to explore tourist satisfaction. Journal of Travel Research, 58(2), 253-265.

Nezakati, H., Amidi, A., Jusoh, Y. Y., Moghadas, S., Aziz, Y. A., \& Sohrabinezhadtalemi, R. (2015). Review of social media potential on knowledge sharing and collaboration in tourism industry. Procedia-social and behavioral sciences, 172, 120-125.

Sema, P. (2013). Does social media affect consumer decision-making?

Senders, A., Govers, R., \& Neuts, B. (2013). Social media affecting tour operators' customer loyalty. Journal of travel \& tourism marketing, 30(1-2), 41-57.

Siddiqui, S., \& Singh, T. (2016). Social media its impact with positive and negative aspects. International Journal of Computer Applications Technology and Research, 5(2), 71-75.

Sigala, M., \& Marinidis, D. (2009). Exploring the transformation of tourism firms' operations and business models through the use of web map services. Paper presented at the European and Mediterranean conference on information systems.

Simms, A., \& Gretzel, U. (2013). Planning a vacation using social media: Influences of demographic, psychographic, and trip-related characteristics. Paper presented the Proceeding of The 20th IFITT International Conference on Information Technology and Travel \& Tourism, ENTER 2013.

Turcotte, J., York, C., Irving, J., Scholl, R. M., \& Pingree, R. J. (2015). News recommendations from social media opinion leaders: Effects on media trust and information seeking. Journal of Computer-Mediated Communication, 20(5), 520-535.

Utz, S. (2010). Show me your friends and I will tell you what type of person you are: How one's profile, number of friends, and type of friends influence impression formation on social network sites. Journal of Computer-Mediated Communication, 15(2), 314-335.

Xiang, Z., \& Gretzel, U. (2010). Role of social media in online travel information search. Tourism Management, 31(2), 179-188. sdoi:https://doi.org/10.1016/j.tourman.2009.02.016

Yogesh, F., \& Yesha, M. (2014). Effect of social media on purchase decision. Pacific Business Review International, 6(11), 45-51. 
Yoo, K.-H., \& Gretzel, U. (2011). Influence of personality on travel-related consumergenerated media creation. Computers in Human Behavior, 27(2), 609-621.

Zeng, B., \& Gerritsen, R. (2014). What do we know about social media in tourism? A review. Tourism Management Perspectives, 10, 27-36.

doi:https://doi.org/10.1016/j.tmp.2014.01.001 